Table 1 Selected hair loss treatments in development

\begin{tabular}{|c|c|c|c|}
\hline Company & Compound & Mechanism & Status \\
\hline Merck & Propecia (finasteride) & $\begin{array}{l}\text { Steroid 5a-reductase inhibitor; blocks conver- } \\
\text { sion of testosterone to dihydrotestosterone } \\
\text { (DHT) }\end{array}$ & Approved \\
\hline GlaxoSmithKline & Avodart (dutasteride) & $\begin{array}{l}\text { Steroid 5a-reductase inhibitor; blocks conver- } \\
\text { sion of testosterone to DHT }\end{array}$ & Phase 3 \\
\hline Allergan & Latisse (bimatoprost) & Prostaglandin F receptor/PGF2 $\alpha$ receptor & Phase 3 \\
\hline Cosmo & CB-03-01 & $\begin{array}{l}\text { Androgen receptor antagonist derived from } \\
\text { 11-deoxycortisone; blocks testosterone and } \\
\text { DHT from binding receptor }\end{array}$ & Phase 2 \\
\hline Samumed & SM04554 & WNT pathway stimulator & Phase 2 \\
\hline Allergan & $\begin{array}{l}\text { Setipiprant (ACT- } \\
\text { 129968) }\end{array}$ & $\begin{array}{l}\text { An oral antagonist of chemoattractant receptor- } \\
\text { homologous molecule CRTH2, expressed on } \\
\text { T helper } 2 \text { cells, and a cognate receptor for } \\
\text { prostaglandin D2. }\end{array}$ & IND \\
\hline $\begin{array}{l}\text { Tetralogic } \\
\text { Pharmaceuticals }\end{array}$ & $\begin{array}{l}\text { SHAPE (suberohy- } \\
\text { droxamic acid phenyl } \\
\text { ester) }\end{array}$ & Histone deacetylase inhibitor & IND \\
\hline
\end{tabular}

IND, investigational new drug.

Cotsarelis' laboratory at the University of Pennsylvania. Cotsarelis' team found that prostaglandin PGD2 is upregulated in the follicular epithelial cells of balding scalps, and that inhibiting its activity triggers hair growth in isolated follicles (Sci. Transl. Med. 4, 126134, 2012). The University of Pennsylvania patented rights to PGD2 receptor antagonists for the treatment of hair loss and licensed that technology to Kythera Biopharmaceuticals of Westlake Village, California, which was acquired last October by Allergan in a cash deal worth $\$ 2.1$ billion. The deal gave Allergan rights to Kythera's oral PGD2 inhibitor, setipiprant, which binds to PGD2's receptor. Kythera had licensed setipiprant from its initial developer, Actelion of Allschwil, Switzerland. The Swiss biotech had tested the drug in patients with allergic and inflammatory conditions, but it had proved ineffective.

Drug developers are still pursuing better compounds to stop DHT from miniaturizing hair follicles than those currently on the market. The oral DHT inhibitor Propecia, also used in a higher dose for treating enlarged prostates, slows hair loss but has potential side effects that include impotence and dizziness. Moreover, the drug is approved only for men, since exposures during pregnancy can harm the fetus.

Instead, Cassiopea of Milan, Italy is developing a topical DHT antagonist called Breezula for alopecia treatment. According to the company's chief executive officer, Diana Harbort, the drug breaks down into harmless byproducts on entering circulation. If approved, Breezula would be the first anti-DHT compound available for use in both men and women. Currently a boutique firm specializing in dermatology, Cassiopeia was spun off by its parent company, Cosmo Pharmaceuticals, in January 2015. It's now publicly traded on the Swiss stock exchange and retains the rights to Breezula, but Cosmo owns nearly half the company's stock.

Breezula's active ingredient, cortexelone $17 \alpha$-propionate, binds the DHT receptor while also reducing PGD2 production in the skin. In a phase 1 study, 18 men and 2 women were exposed to the drug twice daily for 28 days. Researchers used electrophoresis to open skin pores during the study, which generated no evidence of systemic side effects. Breezula is currently being tested against Rogaine and placebo in a 26-week proof of concept study with two primary endpoints: scalp darkness and patient satisfaction. Ken Washenik, a dermatologist and medical director of the Bosley Medical Center, a private practice in Beverly Hills, California, says that unlike Propeciawhich cuts the production of DHT-Breezula has the more beneficial effect of blocking the hormone's receptor. That way, he says, "no matter where in the body DHT is produced, its miniaturizing activity is blocked once it reaches the follicle."

Cotsarelis says that in gauging future prospects for alopecia treatment, it's important to have realistic expectations. "I'd hate to use the word cure, because I don't think male-pattern baldness can be completely reversed," he says. "Instead, we'll develop different treatments, and as with other personalized therapies in medicine, some will work better in various subgroups than others." To illustrate, Cotsarelis cites evidence from his lab showing that PGD2 inhibitors work in only about two-thirds of the cultured hair follicles obtained from various donors. What that suggests, he says, is that some people are innately immune to the effects of PGD2 treatment, probably for genetic reasons. One day, he says, "we'll be looking at genomic screening results to predict who responds to a given treatment and who doesn't."

Charles Schmidt Portland, Maine
CRISPR patents to go on trial

The dispute over who owns the intellectual property rights to the game-changing genome editing system CRISPR-Cas heated up in January after the US Patent and Trademark Office's Patent Trial and Appeal Board said it would decide the fate of the patents in a trial-like procedure called an interference proceeding. The first patent for the CRISPRCas system was granted in April 2014 to Feng Zhang, a bioengineer at the Broad Institute and founder of Editas Medicine, both in Cambridge, Massachusetts (Nat. Biotechnol. 32, 599-601, 2014). Zhang's patent application was preceded by one submitted by Jennifer Doudna, a biochemist at the University of California, Berkeley, and her co-inventors. Attorneys for both parties have been battling ever since. Their arguments center on who first demonstrated a method for editing a mammalian genome using CRISPR-Cas. The US patent office operates under a first-to-file system for granting patents, but Zhang and Doudna's applications are being judged under the old first-to-invent rules owing to their filing and priority dates. Doudna's attorneys in April 2015 requested the interference proceeding against Zhang's patent, number 8697359 , and nine other CRISPRrelated patents he has since filed. The contest was recommended by a patent office examiner on December 21, 2015. The Patent Trial and Appeal Board on January 11, 2016 gave the go-ahead for the interference proceeding in a way that evens the playing field for both parties. Such contests are often lengthy and can involve testimony from inventors.

\section{Bayer joins CRISPR}

Bayer's LifeScience Center has selected Baseland Cambridge, Massachusetts-based CRISPR Therapeutics to be its first investment. The newly established strategic innovation unit, which reports directly to Bayer management in Leverkusen, Germany, is forming a 50-50 joint venture with CRISPR to develop systemic in vivo therapies for blood disorders, blindness and congenital heart disease. Bayer will provide at least $\$ 300$ million in research and development funding to the endeavor over the next five years. It is also acquiring a minority stake in the gene editing specialist for an additional \$35 million. Know-how derived from the collaboration's efforts using the CRISPRCas9 endonuclease system outside of the three disease areas, including target delivery technologies, will exclusively be made available to CRISPR Therapeutics for human use and to Bayer for non-human uses such as agricultural applications. The joint venture will be based in London with operations in Cambridge. Last October, Boston-based Vertex paid \$105 million up front, including a $\$ 30$ equity investment, to set up a research collaboration with CRISPR that includes programs aimed at mutations and genes known to cause and contribute to cystic fibrosis and sickle cell disease. In January 2015, fellow gene editing specialist Intellia Therapeutics, also in Cambridge, partnered with Basel-based Novartis to engineer chimeric antigen receptor $T$ (CAR-T) cells and hematopoietic stem cells using gene editing, marking the first biotech-pharma deal for a CRISPR-Cas9 technology. 